Thorax, 1981, 36, 435-440

\title{
Circulating catecholamines in exercise and hyperventilation induced asthma
}

\author{
P J BARNES, M J BROWN, M SILVERMAN, AND C T DOLLERY \\ From the Departments of Medicine, Clinical Pharmacology, and Child Health, \\ Hammersmith Hospital, London
}

\begin{abstract}
Plasma noradrenaline, adrenaline, and cyclic $3^{\prime} 5^{\prime}$ AMP (cAMP) were measured in seven asthmatic patients with known exercise-induced bronchospasm and six matched non-atopic control subjects during a standard treadmill exercise test and then during matched isocapnic hyperventilation. Normal subjects showed a 5.5 fold rise in noradrenaline and a 3.2 fold rise in adrenaline during exercise compared with a $2 \cdot 1$ fold rise in noradrenaline and no significant rise in adrenaline in asthmatics who all developed bronchoconstriction after exercise (mean fall in peak flow rate $28.4 \pm 5.8 \%$ ). Plasma cAMP rose 1.4 fold in controls but showed no significant rise in asthmatics. This reduced sympatho-adrenal response to exercise in asthmatics is difficult to explain. The failure of circulating catecholamines to rise and stimulate beta adrenoceptors on the mast cell may facilitate the release of bronchoconstrictor mediators. Matched hyperventilation produced bronchospasm in asthmatics (mean fall in peak flow rate $29 \cdot 0 \pm 4 \cdot 4 \%$ ) but no change in catecholamines in either group suggesting that circulating catecholamines have no direct role in exercise-induced bronchospasm but may play a permissive role via the mast cell.
\end{abstract}

Beta-adrenoceptor antagonists such as propranolol cause an increase in bronchial tone in asthmatics but not in normal subjects, ${ }^{12}$ suggesting that the airways of asthmatics are under tonic betaadrenoceptor stimulation. However, intrapulmonary sympathetic innervation of airway smooth muscle has not been demonstrated convincingly in man, ${ }^{34}$ and this indicates that pulmonary betaadrenoceptors may be under the control of circulating catecholamines. Few studies have explored the role of circulating catecholamines in asthma partly because of the difficulties in assaying plasma adrenaline and noradrenaline. Recently, a sensitive and specific radioenzymatic assay has been developed $^{5}$ which we have used in the present study.

Exercise induced asthma (EIA) is a wellrecognised phenomenon but the mechanism remains uncertain. In normal subjects there is a rise in circulating catecholamine levels during exercise, ${ }^{67}$ but it is possible that there may be some abnormality in the catecholamine response to

Address for reprint requests : Dr Peter Barnes, Department of Medicine, Hammersmith Hospital, Du Cane Road, London W12 0HS. exercise in asthmatics with EIA. It has recently been established that the initiating stimulus in EIA is the temperature and humidity change (heat flux) that occurs in the upper airways as a result of the hyperventilation in exercise, ${ }^{89}$ and it is possible to produce similar degrees of bronchoconstriction with matched isocapnic hyperventilation at rest. ${ }^{10}$ We therefore compared the plasma catecholamine change occurring in response to exercise and matched hyperventilation in asthmatics with that in non-atopic control subjects.

\section{Methods}

Seven male asthmatic patients (all with multiple positive skin tests to common allergens) with known exercise-induced asthma who attended an asthma clinic and six male non-atopic control subjects from a nearby school were studied. There was no significant difference in age, height, weight, or physical fitness between the groups. The mean baseline peak expiratory flow rate (PEFR) of the asthmatics was lower but not significantly different from that of the controls (table 1). Research 
Table 1 Anthropometric data in asthmatic and control subjects (mean $\pm S E M$ )

\begin{tabular}{lcccc}
\hline & $\begin{array}{l}\text { Asthmatic } \\
\text { patients } \\
(n=7)\end{array}$ & $\begin{array}{l}\text { Control } \\
\text { subjects } \\
(n=6)\end{array}$ & Difference \\
\hline Age (yr) & $16 \cdot 3 \pm 0 \cdot 9$ & $16 \cdot 5 \pm 0 \cdot 6$ & NS \\
Height (cm) & $169 \pm 5 \cdot 3$ & $173 \pm 3 \cdot 5$ & NS \\
Weight (kg) & $59 \cdot 9 \pm 4 \cdot 2$ & $60 \cdot 3 \pm 3 \cdot 7$ & NS \\
PEFR Actual $\left(1\right.$ min $\left.^{-1}\right)$ & $396 \pm 48$ & $504 \pm 48$ & NS \\
$\quad$ Predicted & $525 \pm 37$ & $546 \pm 25$ & NS \\
\hline
\end{tabular}

Ethics Committee approval for the study was obtained and all subjects gave informed consent. All asthmatics were asymptomatic at the time of study. None was taking systemic corticosteroids; two asthmatics were taking inhaled salbutamol regularly and one intermittently. All medication was stopped at least 12 hours before study. All subjects were tested at the same time of day.

A small cannula was inserted into a forearm vein and the subject rested for 30 minutes. Blood $(5 \mathrm{ml})$ was withdrawn into a prechilled tube with $0.1 \% \mathrm{M}$ EDTA, centrifuged at $4^{\circ} \mathrm{C}$ and the plasma frozen $\left(-80^{\circ} \mathrm{C}\right)$. Plasma adrenaline and noradrenaline were measured by a radioenzymatic method $^{5}$ with a sensitivity of $0.06 \mathrm{nmol} / 1$ and within-assay coefficient of variation of $3.5 \%$. Plasma cyclic $3^{\prime} 5^{\prime}$ AMP (cAMP) was measured by a competitive protein binding assay (Amersham Kit TRK 432). PEFR was measured using a Wright Peak Flow Meter and heart rate recorded electrocardiographically. Each subject then performed a standard exercise test ${ }^{11}$ on a treadmill with a slope of six degrees at six $\mathrm{kph}$ for six minutes. Blood was sampled and PEFR measured during the last minute of exercise. During the exercise subjects wore a nose clip and breathed through a low resistance mobile valve. Inspired minute ventilation was measured by a dry gas meter (Parkinson Cowan CD4), expired gas was continuously sampled for $\mathrm{CO}_{2}$ (Godart infra red analyser) and recorded by ink jet chart recorder (Mingograf 81). After exercise the subject sat and PEFR was recorded at one minute, then blood sampled and PEFR recorded at five, 15, and 30 minutes.

Subjects rested for at least two hours to avoid the refractory period during which a second exercise test causes less bronchospasm, ${ }^{12}$ and then performed a voluntary hyperventilation test. After baseline blood samples had been taken, subjects hyperventilated while seated to achieve a "target" minute ventilation which was identical to that recorded during exercise. The target consisted of an electrically driven revolving pointer fixed over the dial of the gas meter. End-tidal $\mathrm{CO}_{2}$ was adjusted to that measured during the exercise test by adding $100 \% \mathrm{CO}_{2}$ to the inspired air. Subjects hyperventilated for six minutes and blood was sampled during the last minute. PEFR was recorded at the end of hyperventilation again one minute later. Blood samples and PEFR measured were taken at five, 15 , and 30 minutes after hyperventilation.

Results were analysed by Student's $t$ test. All results show mean with standard errors.

\section{Results}

There was no significant difference between the asthmatic and non-atopic subjects in either maximum minute ventilation or in heart rate increase during exercise (table 2). There was no significant change in PEFR of controls during or after exercise but in asthmatics, after a small rise during exercise there was a fall in PEFR of $29 \cdot 4 \pm 5.8 \%$ five minutes after exercise, and return to baseline values 25 minutes later (fig 1).

There was no significant difference between baseline plasma adrenaline, noradrenaline, or cAMP between the two groups (table 3 ). In control subjects there was a 5.5 fold rise in noradrenaline and 3.2 fold rise in adrenaline during exercise. However, in asthmatics noradrenaline rose $2 \cdot 1$ fold and there was no significant rise in adrenaline (fig 1). Plasma cAMP rose 1.4 fold in controls but showed no significant rise in asthmatics (fig 2). The difference in response between groups was significant $(\mathrm{p}<0 \cdot 001)$ for adrenaline, noradrenaline, and cAMP.

With hyperventilation there was no significant change in PEFR in controls but a mean fall of $29.0 \pm 5.4 \%$ after five minutes in asthmatics. In each individual the fall in PEFR with matched hyperventilation was similar to the fall after exercise. There was no significant change in plasma adrenaline, noradrenaline or cAMP during hyperventilation in either asthmatics or controls. Nor was there any significant rise in adrenaline or nor-

Table 2 Heart rate and ventilation response to exercise in asthmatic patients and control subjects (mean $\pm S E M$ )

\begin{tabular}{|c|c|c|c|}
\hline & $\begin{array}{l}\text { Asthmatic } \\
\text { patients }\end{array}$ & $\begin{array}{l}\text { Control } \\
\text { subjects }\end{array}$ & Difference \\
\hline $\begin{array}{l}\text { Resting heart rate }\left(\mathrm{min}^{-1}\right) \\
\text { Maximum heart rate during } \\
\text { exercise }\left(\mathrm{min}^{-1}\right)\end{array}$ & $\begin{aligned} 77 \cdot 7 & \pm 3 \cdot 5 \\
162 \cdot 7 & \pm 1 \cdot 4\end{aligned}$ & $\begin{array}{r}71 \cdot 6 \pm 4 \cdot 8 \\
155 \cdot 8 \pm 3 \cdot 9\end{array}$ & $\begin{array}{l}\text { NS } \\
\text { NS }\end{array}$ \\
\hline $\begin{array}{l}\text { Maximum ventilation during } \\
\text { exercise }\left(1 \mathrm{~min}^{-1}\right)\end{array}$ & $46 \cdot 0 \pm 2 \cdot 4$ & $53 \cdot 0 \pm 3 \cdot 5$ & NS \\
\hline
\end{tabular}




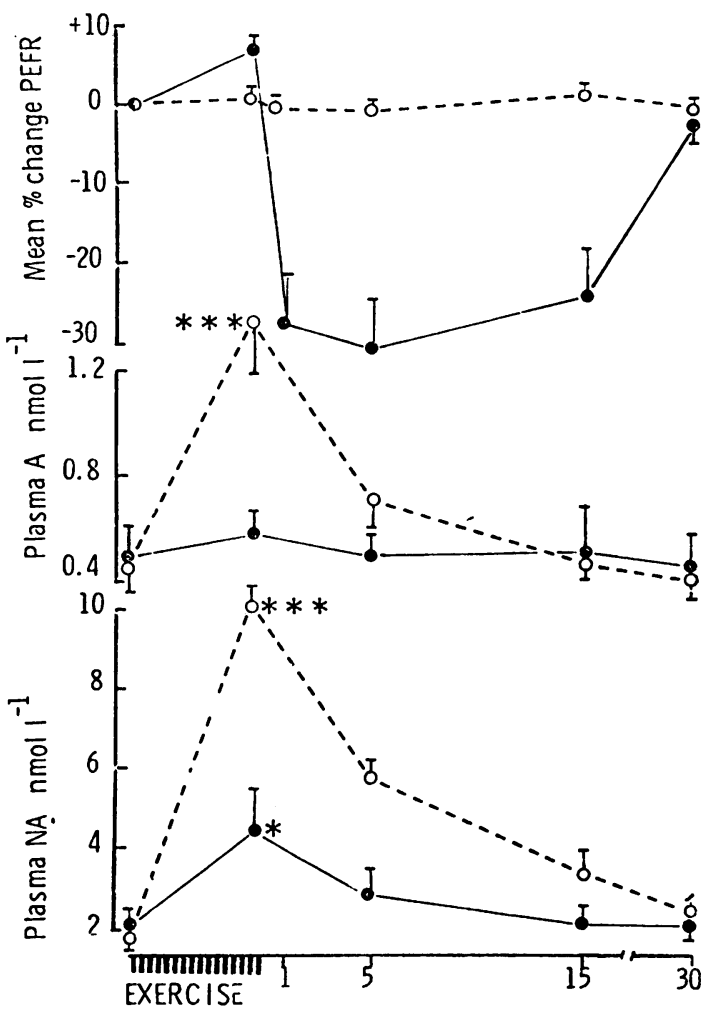

Minutes after exercise

Fig 1 Changes in PEFR and plasma catecholamines with exercise in seven asthmatic patients $(\bullet)$ and six control subjects $(O)$. Results show mean $\pm S E M$. $* * *=p<0.001, *=p<0.05$.
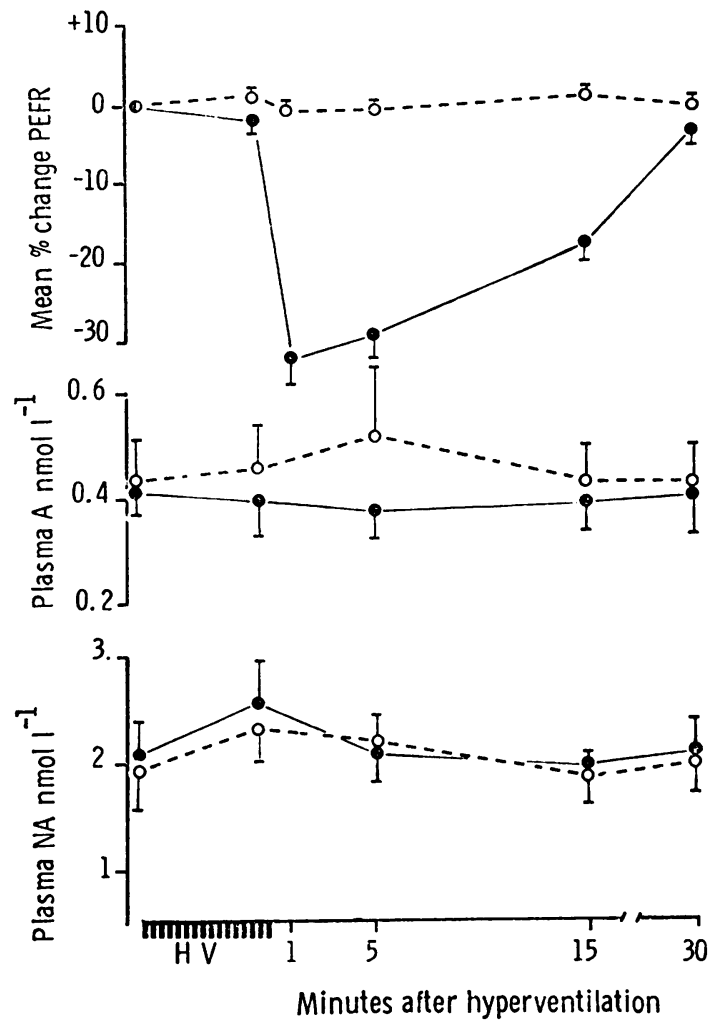

Fig 3 Changes in PEFR and plasma catecholamines with voluntary hyperventilation in seven asthmatic patients $(\bullet)$ and six control subjects $(\bigcirc)$.

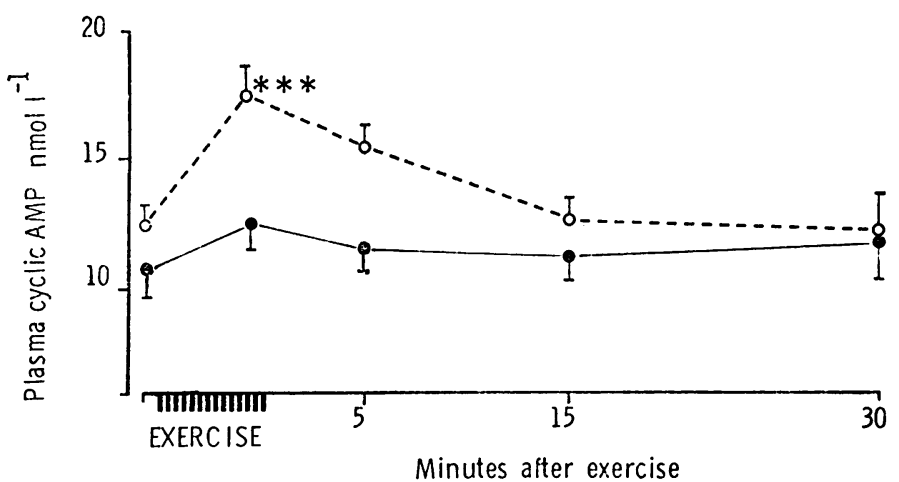

Fig 2 Changes in plasma cyclic AMP with exercise in seven asthmatic patients $(\bullet)$ and six control subjects $(O)$. 
Table 3 Plasma catecholamine and cAMP changes before, during, and after exercise in asthmatic patients and control subjects (mean $\pm S E M$ )

\begin{tabular}{|c|c|c|c|c|c|c|}
\hline & \multicolumn{2}{|l|}{ Baseline } & \multicolumn{2}{|c|}{ During exercise } & \multicolumn{2}{|c|}{ Five minutes after exercise } \\
\hline & $\begin{array}{l}\text { Control } \\
\text { subjects }\end{array}$ & $\begin{array}{l}\text { Asthmatic } \\
\text { patients }\end{array}$ & $\begin{array}{l}\text { Control } \\
\text { subjects }\end{array}$ & $\begin{array}{l}\text { Asthmatic } \\
\text { patients }\end{array}$ & $\begin{array}{l}\text { Control } \\
\text { subjects }\end{array}$ & $\begin{array}{l}\text { Asthmatic } \\
\text { patients }\end{array}$ \\
\hline $\begin{array}{l}\text { Plasma noradrenaline } \\
\left(\text { nmol }^{-1}\right)\end{array}$ & $1 \cdot 81 \pm 0 \cdot 25$ & $2 \cdot 17 \pm 0 \cdot 46$ & $9 \cdot 80 \pm 0.58$ & $4.46 \pm 1.03$ & $5 \cdot 82 \pm 0 \cdot 28$ & $2 \cdot 79 \pm 0 \cdot 60$ \\
\hline $\begin{array}{l}\text { Plasma adrenaline } \\
\left(\mathrm{nmol} \mathrm{1^{-1 } )}\right.\end{array}$ & $0.43 \pm 0.06$ & $0.50 \pm 0 \cdot 13$ & $1 \cdot 39 \pm 0 \cdot 18$ & $0.58 \pm 0.08$ & $0 \cdot 72 \pm 0 \cdot 11$ & $0.50 \pm 0.07$ \\
\hline Plasma cAMP (nmol 1-1) & $12.5 \pm 0.64$ & $10.8 \pm 0.82$ & $17 \cdot 3 \pm 0.96$ & $12 \cdot 5 \pm 0.80$ & $15.5 \pm 0.65$ & $11.5 \pm 0.75$ \\
\hline
\end{tabular}

Table 4 Plasma catecholamine and cAMP changes before, during, and after hyperventilation in asthmatic patients and control subjects

\begin{tabular}{|c|c|c|c|c|c|c|}
\hline & \multicolumn{2}{|l|}{ Baseline } & \multicolumn{2}{|c|}{ During hyperventilation } & \multicolumn{2}{|c|}{ Five minutes after hyperventilation } \\
\hline & $\begin{array}{l}\text { Control } \\
\text { subjects }\end{array}$ & $\begin{array}{l}\text { Asthmatic } \\
\text { patients }\end{array}$ & $\begin{array}{l}\text { Control } \\
\text { subjects }\end{array}$ & $\begin{array}{l}\text { Asthmatic } \\
\text { pa.ients }\end{array}$ & $\begin{array}{l}\text { Control } \\
\text { subjects }\end{array}$ & $\begin{array}{l}\text { Asthmatic } \\
\text { patients }\end{array}$ \\
\hline $\begin{array}{l}\text { Plasma noradrenaline } \\
(\text { nmol 1-1) }\end{array}$ & $1.90 \pm 0.28$ & $2 \cdot 07 \pm 0 \cdot 27$ & $2 \cdot 32 \pm 0 \cdot 27$ & $2 \cdot 56 \pm 0 \cdot 37$ & $2 \cdot 17 \pm 0 \cdot 28$ & $2 \cdot 13 \pm 0 \cdot 30$ \\
\hline $\begin{array}{l}\text { Plasma adrenaline } \\
\left(\text { nmol 1 }^{-1}\right)\end{array}$ & $0.43 \pm 0.07$ & $0.42 \pm 0.04$ & $0.46 \pm 0.09$ & $0.40 \pm 0.08$ & $0.52 \pm 0 \cdot 14$ & $0 \cdot 37 \pm 0.05$ \\
\hline Plasma cAMP (nmol 1-1) & $13 \cdot 4 \pm 0 \cdot 78$ & $11.9 \pm 0.81$ & $12 \cdot 8 \pm 0.80$ & $12 \cdot 3 \pm 0.84$ & $13 \cdot 1 \pm 0.62$ & $13 \cdot 2 \pm 0 \cdot 75$ \\
\hline
\end{tabular}

adrenaline during the period of maximum bronchoconstriction after hyperventilation (table 4, fig 3).

\section{Discussion}

All subjects exercised at the same work load and had a similar ventilatory and circulatory response, yet there was a marked difference in catecholamine response between asthmatic and non-atopic control subjects. In controls plasma adrenaline rose threefold during exercise but in asthmatics there was no significant rise, while plasma noradrenaline showed a five-fold rise in controls but only a twofold rise in asthmatics. This impaired catecholamine response to exercise in asthmatics with exercise-induced asthma is difficult to explain. Bronchodilator medication is unlikely to be responsible for the difference since only three of the asthmatics were taking beta-adrenergic treatment. Moreover salbutamol, when given either orally or by inhalation has had no significant effect on circulating catecholamines in normal subjects (unpublished observations). Circulating noradrenaline is derived mainly from overspill from adrenergic nerves, ${ }^{13}{ }^{14}$ and since the sympathetic innervation of human lung is relatively insignificant, ${ }^{3}$ it is unlikely that the difference between asthmatics and normal subjects reflects any difference in pulmonary sympathetic innervation. Plasma adrenaline is derived solely from the adrenal medulla. It is possible that the difference is caused by increased clearance of catecholamines in asthmatics. This seems unlikely, since baseline values are not significantly different from the normal subjects and $\stackrel{\unrhd}{\unrhd}$ infused adrenaline in asthmatics shows a similar $\overrightarrow{\vec{O}}$ clearance to that in normal subjects (unpublished $\frac{3}{3}$ observations). These results therefore imply a generalised defect in the sympathoadrenal response to exercise in asthmatics who develop EIA. The impaired rise in plasma cAMP during exercise in 으 asthmatics is correlated with the absent rise in $\underset{x}{ }$ circulating adrenaline.

These findings are at variance with other studies which report either no difference in catechola- 0 mines during exercise between asthmatic and normal subjects, ${ }^{15} 16$ or an exaggerated rise during 9 exercise. ${ }^{1718}$ However, in these studies the work $\frac{D}{2}$ load was higher and plasma catecholamines were measured by fluorimetric methods which are rela- N tively insensitive and non-specific in estimating cir- $N$ culating catecholamines. Other studies have shown 요 an impaired rise in free fatty acids after exercise ${ }^{19} \mathrm{\omega}$ and an impaired rise in plasma cyclic AMP during? exercise in asthmatics, ${ }^{20}$ which would be consistent ${ }^{\circ}$ with an impaired sympatho-adrenal response to exercise in asthmatics.

Is the impaired catecholamine response in $\frac{0}{0}$ asthmatics specific for exercise? Mathé and Knapp $\underset{\mathbb{D}}{\mathbb{D}}$ demonstrated an impaired catecholamine response $\frac{\Omega}{\mathbb{Q}}$ to mental stress in asthmatics. ${ }^{21}$ Insulin tol- 응 erance tests in asthmatics provoke a normal hypoglycaemia-induced increase in plasma adrenaline, 8 however, suggesting that the sympatho-adrenal 
defect may be specific for exercise (unpublished observations).

It is possible that this impaired sympatho-adrenal response to exercise could be important in the pathophysiology of exercise-induced bronchoconstriction. Stimulation of beta-adrenoceptors on pulmonary mast cells inhibits the release of bronchoconstrictor mediators such as histamine and slow-reacting substance of anaphyllaxis. ${ }^{22} 23$ The impaired rise in circulating catecholamines in asthmatics may therefore make release of mediators more likely to occur. It is also possible that the small noradrenaline rise in asthmatics in the absence of a rise in adrenaline may stimulate alpha-adrenoceptors on mast cells causing increased mediator release. ${ }^{24}$ In support of this, it has been shown that arterial histamine levels rise during exercise in asthmatics but not in normal subjects. ${ }^{25}$

Voluntary hyperventilation caused a similar bronchoconstriction response to the exercise stimulus in asthmatic subjects, yet there was no significant change in circulating catecholamines. This makes it unlikely that circulating catecholamines control bronchial tone directly but it is possible that hyperventilation causes release of mediators from sensitised pulmonary mast cells, which are not protected by a rise in circulating catecholamines.

The reduced sympatho-adrenal response to exercise in asthmatics with EIA, although difficult to explain, may play a role in the pathogenesis of bronchoconstriction by a permissive action on the mast cell.

We are grateful to Marion Tooley for technical assistance. This work was supported by Medical Research Council Program Grant G971/16/C.

\section{References}

1 McNeill RS, Ingram CG. The effect of propranolol on ventilatory function. Am J Cardiol 1966; 18:473-5.

2 Richardson PS, Sterling GM. Effect of betaadrenergic receptor blockade on airway conductance and lung volume in normal and asthmatic subjects. Br Med J 1969; 3:143-5.

3 Richardson JB, Béland J. Nonadrenergic inhibitory nervous system in human airways. $J$ Appl Physiol 1976; 41:764-71.

4 Richardson JB. Nerve supply to the lungs. Am Rev Respir Dis 1979; 119:785-802.

5 Da Prada M, Zurcher G. Simultaneous radioenzymatic determination of plasma and tissue adrenaline, noradrenaline and dopamine within the femtomole range. Life Sci 1976; 19:1161-74.

6 Vendsalu A. Studies on adrenaline and noradrenaline in human plasma. Acta Physiol Scand 1960; 49: suppl 173.

7 Häggendal J, Hartley LH, Saltin B. Arterial noradrenaline concentration during exercise in relation to relative work levels. Scand J Clin Lab Invest 1970; 26:337-42.

8 Strauss RH, McFadden ER, Ingram RH, Chandler E. Influence of heat and humidity on the airway obstruction induced by exercise in asthma. $J$ Clin Invest 1978; 61:433-40.

9 McFadden ER, Ingram RH. Exercise-induced asthma. N Engl J Med 1979; 301:763-9.

10 Kilham H, Tooley M, Silverman M. Running, walking and hyperventilation causing asthma in children. Thorax 1979; 34:582-6.

11 Silverman M, Anderson SD. The standardisation of exercise tests in asthmatic children. Arch Dis Child 1972; 47:882-9.

12 Edmunds AT, Tooley M, Godfrey S. The refractory period after exercise-induced asthma. Its duration and relation to the severity of exercise. Am Rev Respir Dis 1978; 117:247-54.

13 v Euler US, Franksson C, Hellström J. Adrenaline and noradrenaline output in urine after unilateral and bilateral adrenalectomy in man. Acta Physiol Scand 1954; 31:1-12.

14 Cousineau D, Ferguson RJ, de Champlain J, Gauthier P, Côté P, Bourassa M. Catecholamines in coronary sinus during exercise in man before and after training. J A ppl Physiol 1977; 43:801-6.

15 Anderson SD, Pojer R, Smith ID, Temple D. Exercise related changes in plasma levels of 15keto-13, 14-dihydroprostaglandin $\mathrm{F}_{2} \alpha$ and noradrenaline in asthmatic and normal subjects. Scand J Respir Dis 1976; 57:41-8.

16 Chryssanthopoulos C, Barboriak JJ, Fink JN, Stekiel WJ, Maksud MG. Adrenergic responses of asthmatic and normal subjects to submaximal and maximal work levels. J Allergy Clin Immunol 1978; 61:17-22.

17 Griffiths J, Leung FY, Grzybowski S, Moira MW, Chan-Yeung MB. Sequential estimation of plasma catecholamines in exercise induced asthma. Chest 1972; 62:527-33.

18 Beil M, Brecht HM, Rasche B. Plasma catecholamines in exercise induced bronchoconstriction. Klin Wschr 1977; 55:577-81.

19 Barboriak JJ, Sosman AJ, Fink NJ, Maksud MG, McConnell LH, Hamilton LH. Metabolic changes in exercise induced asthma. Clin Allergy 1973; 3:83-9.

20 Hartley JPR, Davies CJ. Plasma cyclic nucleotides in exercise-induced asthma. Thorax 1978; 33:668.

21 Mathé AA, Knapp PH. Decreased plasma free fatty acids and urinary epinephrine in bronchial asthma. N Engl J Med 1969; 281:234-8.

22 Orange RP, Kaliner MA, Laraia PJ, Austen KF. Immunological release of histamine and slow re- 
acting substance of anaphylaxis from human lung. 24 Kaliner M, Orange RP, Austen KF. ImmunologiII. Influence of cellular levels of cyclic AMP. Fed Proc 1971; 30:1725-9.

23 Tomita Y, Patterson R, Suszko IM. Respiratory mast cells and basophiloid cells. II. Effect on $3^{\prime} 5^{\prime}$ adenosine monophosphate content and on antigen-induced histamine release. Int Arch Allergy Appl Immunol 1974; 47:261-72. cal release of histamine and slow reacting substance of anaphylaxis from human lung. IV. Enhancement by cholinergic and alpha-adrenergic stimulation. J Exp Med 1972; 136:556-67.

25 Ferris L, Anderson SD, Temple DM. Histamine release in exercise induced asthma. $\mathrm{Br}$ Med $\mathrm{J}$ 1978; 1:1697. 